\title{
SUPERVISI PENDIDIKAN DALAM MEWUJUDKAN TUJUAN NASIONAL PENDIDIKAN DAN MENINGKATKAN MUTU PENDIDIKAN
}

\author{
ANNAFI SRI NANDA \\ annafisrinanda20@gmail.com
}

\begin{abstract}
ABSTRAK
Pendidikan merupakan suatu kebutuhan bagi setiap manusia. Melalui pendidikan setiap individu dapat memperbaharui pengetahuan yang dimilikinya agar dapat mengikuti perkembangan zaman yang semakin canggih, menuntut agar setiap individu memiliki kemampuan berpikir yang baik. Individu yang memiliki kemampuan berpikir yang baik, akan dapat menyelesaikan permasalahan yang lebih kompleks dibandingkan individu yang kemampuan berpikirnya masih rendah. Kenyataan yang ada, sampai saat ini masih dirasakan bahwa kondisi pendidikan masih kurang baik. Fasilitas belajar masih kurang memadai, baik itu kelengkapan buku yang ada di perpustakaan sekolah, penggunaan laboratorium yang belum dimanfaatkan dengan maksimal, sarana dan prasarana pendidikan yang terbatas, kekurang profesionalan pendidik dalam pengajaran, baik itu dalam menyiapkan bahan ajar maupun dalam menyampaikan materi pelajaran, kurang disiplinya pendidik, serta mesih kurangnya pengetahuan pendidik mengenai proses pembelajaran yang efektif sehingga tujuan pendidikan yang sesungguhnya menjadi tidak tercapai. Ada beberapa alternatif yang dapat dilakukan untuk memecahkan masalah pendidikan. Pertama, memberikan motivasi akan pentingnya supervisi pendidikan bagi pendidik. Kedua, mengupayakan sarana dan prasarana pendidikan yang memadai. Ketiga, menerapkan kedisiplinan pendidik. Pendidik merupakan contoh bagi setiap peserta didik.
\end{abstract}

Kata Kunci :

Pendidikan, Supervisi Pendidikan, Tujuan Pendidikan, Mutu Pendidikan.

\section{LATAR BELAKANG MASALAH}

Pendidikan merupakan suatu kebutuhan bagi setiap manusia. Melalui pendidikan setiap individu dapat memperbaharui pengetahuan yang dimilikinya agar dapat mengikuti perkembangan zaman yang semakin canggih, menuntut agar setiap individu memiliki kemampuan berpikir yang baik. Individu yang memiliki kemampuan berpikir yang baik, akan dapat menyelesaikan permasalahan yang lebih kompleks dibandingkan individu yang kemampuan berpikirnya masih rendah.

Berdasarkan tujuan Pendidikan Nasional yang terdapat dalam Undang-Undang Republik Indonesia No. 20 Tahun 2003 tentang Sistem Pendidikan Nasional, Bab II Pasal 3 yang menyatakan bahwa Pendidikan Nasional memiliki fungsi agar peserta didik mampu untuk mengembangkan kemampuan yang dimilikinya sehingga dapat membentuk watak serta peradaban bangsa yang bermartabat sebagai upaya dalam mencerdaskan kehidupan bangsa.

Demi tercapainya tujuan tersebut maka pendidikan yang dilaksanakan di Indonesia tentu tidaklah terlepas dari standar-standar yang telah ditetapkan sebagaimana yang telah dikemukakan oleh Mulyasa (Mulyasa, 2009). Standar tersebut dimuat dalam PP No. 19 Tahun 2005 yang berupa 8 Standar Nasional Pendidikan yaitu standar kompetensi lulusan, standar isi, standar pendidik dan tenaga kependidikan, standar sarana dan prasarana, stardar pengolaan, standar pembiayaan, dan standar penilaian.

Kenyataan yang ada, sampai saat ini masih dirasakan bahwa kondisi pendidikan masih kurang baik. Fasilitas belajar masih kurang memadai, baik itu kelengkapan buku yang ada di 
perpustakaan sekolah, penggunaan laboratorium yang belum dimanfaatkan dengan maksimal, sarana dan prasarana pendidikan yang terbatas, kekurang profesionalan pendidik dalam pengajaran, baik itu dalam menyiapkan bahan ajar maupun dalam menyampaikan materi pelajaran, kurang disiplinya pendidik, serta mesih kurangnya pengetahuan pendidik mengenai proses pembelajaran yang efektif sehingga tujuan pendidikan yang sesungguhnya menjadi tidak tercapai.

Berdasarkan uraian di atas, permasalahan dalam tulisan ini adalah bagaimana kondisi pendidikan yang seharusnya, bagaimana kondisi supervisi perndidikan yang terjadi dan apa alternatif yang dilakukan untuk memecahkan masalah pelaksanaan pendidikan. Sedangkan tujuan dari tulisan ini adalah untuk mengetahui kondisi pendidikan yang seharusnya, mengetahui kondisi supervisi pendidikan yang terjadi dan mengetahui alternatif yang dilakukan untuk memecahkan masalah pelaksanaan pendidikan.

\section{PEMBAHASAN}

Pendidikan Indonesia hendaknya sesuai dengan tujuan pendidikan nasional yaitu agar peserta didik mampu untuk mengembangkan kemampuan yang dimilikinya sehingga dapat membentuk watak serta peradaban bangsa yang bermartabat sebagai upaya dalam mencerdaskan kehidupan bangsa. Demi tercapainya tujuan ini, hendaknya adanya kerjasama antar pemerintah, pendidik, orang tua dan tenaga kependidikan lainnya.

(Hamalik, 1992) Oemar Hamalik menyatakan bahwa supervisi menjadi penentu utama untuk memutuskan kurikulum, menyeleksi pola-pola organisasi sekilah, fasilitas belajar, dan menilai proses pendidikan secara keseluruhan.

Sebagaimana yang dikemukakan oleh Sabandi (Sabandi, 2013) bahwa supervisor memegang peranan penting dalam meningkatkan kualitas guru agar dapat melaksanakan pembelajaran yang lebih berkualitas. Jabatan supervisor di sekolah meliputi kepala sekolah dan pengawas. Supervisi yang dilakukan oleh kepala sekolah diatur dalam Permen Diknas Nomor 13 Tahun 2007 tentang Standar Kepala Sekolah/Madrasah. Dimensi kompetensi supervisi kepala sekolah yang meliputi: (1) merencanakan program supervisi akademik dalam rangka peningkatan profesionalisme guru, (2) melaksanakan supervisi akademik terhadap guru dengan menggunakan pendekatan dan teknik supervisi yang tepat, dan (3) menindaklanjuti hasil supervisi akademik terhadap guru dalam rangka peningkatan profesionalisme guru. Disamping itu, supervisi yang dilakukan oleh pengawas diatur dalam Permen Diknas Nomor 12 Tahun 2007 tentang Standar Pengawas Sekolah/Madrasah. Dimensi kompetensi pengawas sekolah/madrasah meliputi: (1) kompetensi kepribadian, (2) kompetensi supervisi manajerial, (3) kompetensi supervisi akademik, (4) kompetensi evaluasi pendidikan, (5) kompetensi penelitian pengembangan, dan (6) kompetensisosial. Berdasarkan Permen Diknas nomor 12 tahun 2007 dan Permen Diknas nomor 13 tahun 2007, bahwa kepala sekolah dan pengawas sekolah/madrasah memiliki tanggung jawab dalam meningkatkan profesionalitas guru.

Ada beberapa alternatif yang dapat dilakukan untuk memecahkan masalah pendidikan.Pertama, memberikan motivasi akan pentingnya supervisi pendidikan bagi pendidik. Pemberian moivasi ini bukanlah kegiatan untuk mencari-caari kesalahan pendidikan melainkan kegiatan memberikan mengarahan ataupun motivasi kepada pendidik tentang pentingnya supervisi pendidikan.

Kedua, mengupayakan sarana dan prasarana pendidikan yang memadai. Sarana dan prasarana merupakan suatununsur penting dalam proses pendidikan. Demi tercapainya tujuan pendidikan yang diharapkan pemerintah hendaknya menyediakan sarana dan prasarana yang memadai seperti ketersediaanya buku-buku penunjang pelajaran di perpustakaan.

Ketiga, menerapkan kedisiplinan pendidik. Pendidik merupakan contoh bagi setiap peserta didik. Oleh sebab itu, pendidik harus memberikan contoh yang baik, berprilaku yang 
sopan sesuai dengan norma agar peserta didik juga dapat berprilaku yang baik juga, menjaga sopan santun, dan beretika sesuai dengan norma yang berlaku.

\section{PENUTUP}

\section{KESIMPULAN}

Berdasarkan pembahasan di atas dapat disimpulkan bahwa pendidikan merupakan suatu kebutuhan yang harus dimilki setiap manusia. Tujuan dari pendidikan itu adalah untuk mencerdaskan kehidupan bangsa. Upaya untuk mewujudkan tujuan pendidikan itu perlu adanya kerjasama antara pemerintah, pendidik, orang tua dan tenaga kependidikan. Adapun alternatif yang dapat dilakukan dalam memecahkan masalah pendidikan yaitu memberikan motivasi akan pentingnya supervisi pendidikan, mengupayakan sarana dan prasarana pendidikan yang memadai, dan menerapkan disiplin pendidik.

\section{SARAN}

Saran dalam penulisan ini berdasarkan kesimpulan yang telah diperoleh adalah pemerintah diharapkan bisa memfasilitasi proses pembelajaran dengan sarana dan prasarana yang memadai serta menciptakan pendidik yang profesional, displin dan bertanggung jawab guna untuk mencapai tujuan pendidikan.

\section{REFERENSI}

Hamalik, O. (1992). Administrasi dan Supervisi Pengembangan Kurikulum. Bandung: Mandar Maju.

Mulyasa. (2009). Kurikulum Yang Disempurnakan. Bandung: Remaja Rosdakarya.

Sabandi, A. (2013). SUPERVISI PENDIDIKAN UNTUK PENGEMBANGAN PROFESIONALITAS GURU SUPERVISI PENDIDIKAN UNTUK PENGEMBANGAN PROFESIONALITAS GURU BERKELANJUTAN. Pedagogi, Jurnal Ilmiah Ilmu Pendidikan, XIII(No. 2), 1. Retrieved from http://ejournal.unp.ac.id/index.php/pedagogi/article/view/4275/3345 